\title{
Educational Setup by a Global Repute Company of Greater Noida (Uttar Pradesh) - An Initiative under Corporate Social Responsibility
}

\author{
Priyesha Jain \\ Bhavan's Usha And Lakshmi Mittal Institute of Management, New Delhi, India
}

\begin{abstract}
This report was carried out to divulge the main aspect of a company's social responsibility towards the society, specifically the vicinity in which they are operating. The company has an industrial unit in a village of Greater Noida (Uttar Pradesh) and has adopted the villages within $5 \mathrm{kms}$ of radius. The report provides an analysis and evaluation of current and prospective performance of students enrolled by the trust in a school started by them for the village students. The sample taken was of 55 students of two nearby villages. The method of analysis included questionnaires, interaction with the teachers, students, parents and the employees of the trust, along with that inspection was personally conducted to ensure no loopholes were there and its fixture if any. The findings suggest that the company has to follow some standard procedures to ensure regular attendance of these students enrolled by them. A regular check on the teachers needs to be maintained to match the educational standards expected, so as to fully ensure their responsibility towards the society. The results showed that the engagement of the students in their household chores left them with little time to attend school in case of girl students and various other factors affected the performance of the students overall.
\end{abstract}

Keywords: Corporate Social Responsibility, Impact assessment, student's performance.

\section{Introduction}

"Social responsibility (is the) responsibility of an organisation for the impacts of its decisions and activities on society and the environment through transparent and ethical behaviour that is consistent with sustainable development and the welfare of society; takes into account the expectations of stakeholders; is in compliance with applicable law and consistent with international norms of behaviour; and is integrated throughout the organisation." (Working definition, ISO 26000 Working Group on Social Responsibility, Sydney, February 2007).Corporate social responsibility (CSR is a strategic initiative that needs to be undertaken by every company and industrial units. It needs to be planned carefully while taking in consideration the nearby area, its requirements and what a company can provide to the community in which they are serving their business unit. CSR is mainly a contribution to the society as a whole but more explicitly for the area within which their operations undertake. It's basically a concept of giving in return for the basic utilities or resource in use from the area where it operates. Due to the expansion of businesses and global summon, it has become all the more important for establishments to put in their efforts towards serving the community. A business can only prosper when they go hand in hand with the communities they operate within. According to a study done by Hewitt \& Associates, 230 workplaces with more than 100,000 employees were looked upon and found out that more the company is actively involved in environmentally and socially, the more its employees are engaged with the company. This shows that CSR is not only about contributing to the society but also towards its employees. In addition to that, "The Society of Human Resource Management" found out those companies with highly engaged employees have three times the earnings per share as compared to the companies with low employee engagement due to low sustainability programs. This also throws a light upon the fact that somewhere CSR and Human Resource Management are inter linked with each other. Both the processes involve dealing with people. This adds up to a new dimension of its own which if garnered further could result into a changing the whole scenario of CSR. In more years to come and the speed at which globalization is taking place, Corporate Social Responsibility would keep on changing and growing to meet the demands of the society at large. With active involvement of the establishments, CSR will bring a revolution in how the industries function and it will be beneficial environmentally and socially.

"We are committed to creating economic value, but we are not indifferent to how we do it... Progressive businesses are gaining competitive advantage by responding to societal signals... We prosper by helping society to prosper." (Idar Kreutzer, CEO, Storebrand, 2005). 


\section{Csr Policy Of The Trust}

The CSR initiatives of the trust have aimed at integrating the economic, social, environmental imperatives for ensuring sustainability. With growing years, there came a shift in the modus operandi of the trust into to provide education to the young ones whose parents can't afford to send their children to school or are not willing to provide them education. This also included empowerment of women and girl child.

\section{Structure Of The Csr Wing Of The Trust}

The trust involved in the research report is a community development wing of the main company and is registered under the Indian Truest Act, 1883 and forms a part of the CSR department of the company. The trust has direct involvement in nearby villages of Kakrala, Aagar, Nagla. The study of the students undertaken was from the villages of Kakrala and Aagar.

\section{Objectives Of The Study}

4.1 To assess the impact of the enrolled students under the project of the CSR activity.

4.2 To check the viable reasons behind the increase dropout rate of the students enrolled.

4.3 To highlight the effectiveness of a CSR initiative under taken by the company.

\section{Methodology}

\subsection{Sampling}

The population in this research was students aged 9-12 years from two nearby villages who were enrolled in the school by the company.

5.2 Sampling technique

Purposive sampling technique was used for the research and the sample size taken was of 55 students.

\section{Findings}

6.1 It was found that the female students were more than their male counterparts. Thus, the efforts of the project could be easily seen.

6.2 The attendance was satisfactory which shows that the students were quite regular and they enjoyed coming to the school but some students who were continuously not coming to the school for a long gap were paid a visit in their village to know the reason behind their week long gap.

6.2.1 The reason at hand was that the girls were made to do the house chores as per the frame of mind of the villagers; a girl's priority is her home not education.

6.2.2 The reason behind the boys who were not present in the class was their parents believed that being from an underprivileged society our sons have to follow the footsteps of the male counterpart of the family.

6.3 To assess the performance level of the students, a quick verbal test was conducted where we found that the students were reluctant to answer the questions even though they knew the answer when asked personally. Overall the students were having less confidence to stand up and answer.

6.4 Student's performance was found out to be just average as they were not completing their home assignments. It was a feedback given by the principal as well as the teacher concern.

6.4.1 The reason found out after interacting with the students was that their parents being illiterate couldn't help them out with their studies.

6.4.2 Another reason found out was that the girls specifically had to help their mothers in the household after returning from school.

6.4.3 To assess the performance level of the students, a quick verbal test was conducted where we found that the students were reluctant to answer the questions even though they knew the answer when asked personally. Overall the students were having less confidence to stand up and answer.

6.5 The motivation factor involved was both due to the parents and instructors from the company trust for students to attend the school though the major contribution made was from the mothers who had high influence on their children.

6.6 It was found out that most of the students were able to read, write and speak though they could not match the expected literacy level in comparison to other private schools outside the village.

6.7 Some parents who were concerned about their child's education shifted them to private schools that offered better education after seeing a significant improvement in their child due to the initiative taken up by the company.

6.8 During the study it was found that the teachers were not qualified as per the guidelines of the government but the company ensured an enquiry on this matter. 
6.9 The school lagged behind various parameters such as the class strength exceeded 100 students in one batch, no extracurricular activities were offered to the student which is of prime importance for the age group of 9-12 years and mid day meal given was not consumable.

6.10 A sum of Rs 1200 being ear marked by the govt. did not reach the concerned authorities and only Rs 300 was being provided. The difference in balance figure was unaccountable.

6.11 As per the new government guidelines, the students were to be registered according to their age no matter what they were capable of understanding ie If a student is 10 years old then he/she has to be enrolled in $5^{\text {th }}$ class irrespective of the performance level.

6.12 The teachers justified their inability to teach them properly by making an excuse of not being able to punish the students as corporal punishment was banned by the government.

6.13 Trust provided support classes to weak students free of cost.

6.14 Trust actively conducted monthly follow ups to ensure the overall development of the students and also by arranging PTA meets.

\section{Challenges Faced By The Trust}

There were various challenges that occurred in the implementation of school for the children in the village. These are common issues in villages were maximum population is illiterate.

7.1 The parents were reluctant to send their children to school as they are not aware of its benefits and mainly the importance of education. The trust however with vigorous sessions with the parents was able to convince so of them. The initiative taken by the trust should be implemented on a large scale as education is a field of prime importance.

7.2 There was lack of motivation for the children to go to school as their parents were not supportive.

7.3 Another area of problem was that the parents weren't sure about the safety of their girl child as they were hesitant to let their girl child study in the same class with the boys.

7.4 Children were also involved in the household chores and everyday school activity would require them to set aside the work they were doing before, lessening the total money earned by the family. It was noticed that the work they performed required the involvement of every family member to complete the task which would provide them a sum of Rs. 100 for a week.

\section{Recommendations}

8.1 They should conduct a workshop for the teachers to enhance their own skills and encourage them to develop new teaching tools.

8.2 A proper framework regarding course design should be provided to the resource centre, which is in relevance with the culture of the village community.

8.3 As per the new government guidelines, the trust should make support classes mandatory to the students who are weak in studies.

8.4 The students should be encouraged to discuss about their daily activities with their parents and siblings.

8.5 The teachers should motivate the students by providing them with some sort of non monetary appreciation.

8.6 They should form a group of the existing peer leaders who would only be in charge of the feedback and the problems concerning the students.

\section{Conclusion}

During the study it was found that the initiative taken by the company was definitely an uphill task to educate the future leaders of our country especially their parents about the motivation they need to provide to their children to go to school. It did make an impact and with continuous check and little more involvement, it will positively pay off in future for the betterment of the society. The trust at the same time had been very active in providing quality education. This was done in collaboration with a reputed resource centre which provided the course material for the students. CSR initiative is a duty of every enterprise and the society is its responsibility that needs to be taken care. This is the least a company can perform and its regulation should be mandatory. This will solve two things at the same time, one being the upliftment of the society and secondly, it will generate awareness for the companies to be liable to take this task at hand and put in some part of their earnings in this initiative. 


\section{References}

[1] Elizabeth Real de Oliveira, Pedro Ferreira, Irina Saur- Amaral, Human Resource Management and Corporate Social Responsibility: A systematic literature review, 2nd Conference of the MENA Chapter of Academy of Human Resource Development (AHRD), November 8-10, 2012, Istanbul, Turkey.

[2] "The top 10 trends in CSR for 2012" by Tim Mohin, director of CR for advanced micro devices (introduction)

[3] Agatha Ferijani, Umar Nimran, Margono Setiawan, Surachman, "The Effect of Manager Orientation Concerning To the Corporate Social Responsibility and Manager Typology towards the Effectiveness of Corporate Social Responsibility (CSR) Implementation (A Study in Pt Sido Muncul)", IOSR Journal of Business and Management (IOSR-JBM), 9(6), 2013, 28-36.

[4] Paul Hohnen "Corporate Social Responsibility: An implementation guide for business", International Institute of Sustainable Development, Canada, 2007, 8-12. 